\title{
木造遺構よりみた朝鮮高麗朝建築の様式に関する一考察 \\ A STUDY ON THE ARCHITECTURAL STYLE DURING CHOSEON AND KORYO DYNASTY BY INVESTIGATION OF THE HISTORICAL WOODEN ARCHITECTURES
}

\author{
片桐正夫* \\ Masao KATAGIRI
}

\begin{abstract}
This study is about import of the architectural technique and existence of the form during Koryo and Choseon dynasty, through investigation of the eight(Chu-shimpo style) and four(Ta-po style) wooden architectures of Koryo as well as the trend of Chinese architecture and also the cultural exchange between China and Korea.

This study led to the following results;

1. In case of Chu-shim-po style, the traditional form of united Shilla was changed, using Soiseo-attached-Hiziki, thrust-through-Hiziki and based-capital by influence of the technique and style from Pei-sung and Nan-sung. And by influence

of Ta-po style, it was changed, using straight capital and post of roof structure.

2. In case of Ta-po style, the combination of Soiseo-attached-Hiziki was introduced by import of the new technique and form from Yüan, while Odaruki was not used much.
\end{abstract}

Keywords: Soiseo-attached-Hiziki, Chu-shim-po style, Ta-po style, architecture of Koryo

化精尾垂木，疎組（柱心包系），詰組（多包系），高麗建築

1.はじめに

高麗王朝は、松岳地方（開城市を中心とする地方）の 豪族であり、統一新羅朝の武人でもあった王建によって 918年に開かれ、王宮を開城に置いた。以来、やはり武人 の出身の李成桂に政権を奪われるまで 34 代、恭譲王 4 年 (1392年)に至る 470 年余の長期政権であった。

この時代は、中国においても新しい時代の転換期であ り、漢民族中心の国家運営から、契丹、女真、モンコル など北方民族との抗争之融合の中で多民族共存の国家へ と拡がりを見せ、文化活動にもこのことが当然のことな がら影響し、政治のみでなく、社会的にも変化の時代で あったことは周知のことである。

年表 1 に示したように、朝鮮では、地理的㻴境からも 中国の政変の影響は、日本よりも直接的で、唐朝崩壊後 の民族対立抗争を内包した南北対立王朝の出現は、高麗 政権の国家運営や文化活動にも大きく係わってくること となった。

官僚機楧は建国時代には唐制にならっていたが、やが て北末との交流を通じて、その制度にならった。しかし 、北末にかわって元の支配が強まると共に、開城を離机 て、江華島へ王宮を移すなどの抵抗もあったが、それも 限界となり、元朝に従い、官僚機構のみでなくあらゆる 分野で元の文物が導入されることとなった。（注1，2，3）

このような政治外交状況を背景にした国内体制の運営 にあたって、儒教と仏教の尊重が計られた結果、儒学教 育研究機関が整備され（私学12徒、京師 6 学など）、ま た、仏教は、大蔵経の刻板事業にみられるように新羅時
代以来の国家保護が更に続いていた。

特に、現世利益を求める高麗貴族の信仰心と義天（文 宗の第 4 子。1060年代〜）の天台宗の開宗をきっかけと して興った䎲教改革によって、既に 9 世紀統一新羅時代 末より盛んとなっていた禅宗をもとにした曹溪宗の成立 をもたらすなど、旧新羅仙教とは異なる境地を開くに至 った。

こうした仙教界の活動は、国家保護によって都市部だ けでなく、広く山地に伽藍を求め、その整備がなされた 。建築界は当然こうした時代の要求に応じて、国都王宮 の建設をはじめ、儒学校、寺院の建設を中心とした工事 に係わる中で、発展をとげた。外交及び交易など北末と の親しい関係を背景にして、また、禅宗をはじめ文化的 にも新しい境地を開いて学ぶものの多かったこともあっ て、元朝の成立から、その圧力が半島におよぶまでの間 、高麗朝は、未之の交流を中心としつつ、遼・金の影響 をも受けつつ進んだことが広く知られている。

2.中国唐末から元代に至る木造建築の発展経過

唐末から元代にかけての建築の技術的発展、特に軒組 形式と頭貫(闌額)・台輪(普柏枋)・尾垂木（昂）・さし 时木（挿栱）がどのように進化したのか、遺構をもとに 考察したい。

中国では、唐から元代にかけての遺棈数が㙛造、石造 のものを加えて約140棟余とみられている。この中から 地域、時代、特徵などを考虑して代表的な遗棈（注 4)
* 日本大学理工学部建築学科 助教授・博士 (工学)
Assoc. Prof., Dept. of Architecture, College of Science \& Technology, Nihon University, Dr. Eng. 
をとりあげて考察の対象とする。

軒組の変化のきざしの初見遺構は、唐末の現存遺構仏 光寺大殿（山西 857年）で、台輪にあたる部材（普柏枋 ）は使用されていないが、頭貫 (闌額) は疎組の南禅寺 大殿（山西 782年）のそれより太く（注5）なり、柱間 中備軒組 (二手先の組物) をその上にのせているが、こ れが、詰組形式の前段階の技術的過程を示すものと一般 に解されている。

そして、大雲院大仏殿（山西 後唐 923〜 35年図参照 ）では台輪（普柏枋）が入れられ、その上に、柱上・柱 間共に同形の二手先組物が配されており、いわゆる詰組 系の技術が、唐末から五代にかけての間に、山西省五台 山一带の寺院建築建設の過程で発展したことを示してい るものといえる。

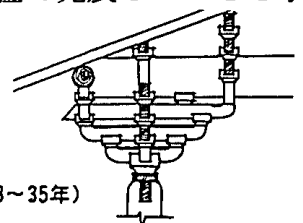

大院大红股（後唐代 923 35年）

『営造方式』（注 6) の刊行された北末1100年には、 台輸（普柏枋）付の詰組の技術が完成していたことが知 られるが、表2（付図）に示したように、900年代前半期 ごろから普及してゆき、900年末から以降には北末の地 のみならず、遼の地にも普及していたことが明らかにな っている。

同時に疎組系の建築は、住宅や付属的な建物に使用さ れる例が多数派となり、一部の例外を除いては、建築界 の先進的技術の系統からはずれる事となった。

表 2 の 5 、華林寺大殿は疎組系の建築であるが、福建 省福州にあって、血斗付斗・さし时木（挿棋）をもつも ので、この地方に我国大仏様のルーツを求めることが定 説となっているが、これを示す一事例である。なお、血 斗、さし时木などの形式は、既に漢代に出現していたも ので、南末代に至るまで、中央から遠くはな扎ていたこ の地に、これらの形式が存在している理由は明らかでは ないが、一般論としては、中央からはなれた地であった ことが、形式としての固定化を助長し、旧来の技術が永 く伝承されることとなったことが指摘されよう。(注 7 )

次に、軒組の変化について遺構を整理してみると(表 2 ) 次の諸点が指摘されよう。前述したように五代以降 疎組系の建築では大きな技術的進展変化がみられた跡が ないが、詰組系では尾垂木 (昂) の形式と使用形態に多 様性がみられる。

时木（華栱）の重ね合わせで軒組みが構成される形式 （ただし柱上のみは梁頭が加わる）は疎組系では南禅寺 大殿（表 2 図1）にみられるように唐代、あるいはそれ 以前からの存在が認めら扎るが、詰組系でも900年代では 独楽寺観音閣（表 2図6）大雲寺大殿（表 2 図 8) など の例がみられ、唐以降もこの形式が使われていたことを 示している。

しかし、地域的にみると、この形式は1000年代以降で は北部のかっての唐朝の中心地域狭西省地方や、唐代仏 跡の多い五台山・山西省を含む地域をその支配地をした 遼、更に金の政権下で建設された建築(表 2 図 9，10，1 1，19，20，21)に多くみられることとなる。

南部北末あるいは南末の地にこの形式をとることは例 外的に存在することはあっても一般的には用いられなく なることが指摘されよう。

次に尾垂木（昂）について見ると、古くは、表 2 図 2 に示すように唐代には、その存在があったものとされる 。尾垂木をもつ我国法隆寺の様式が高句麗系、さらには 北魏系にまでたどることが可能性として高いことを示す 関口欣也博士の論考（注 8 ）また、拙稿（注9）でも述 べたように単純な形式では漢代にそのルーツをたどるこ
とができるなどから、唐代の早い時期には、仙光寺大殿 のような形式が定着していてたものといえよう。

この尼垂木の使用は、南北地域に広くしかも長期間に わたってみられるものであり、軒組の構造上の重要部材 として認識されていたものといえる。

朝鮮でいう牛舌（注10）中国の（仮昂、表2では仮） という部材は、日本では東大寺鐘楼（1207〜10年）を初 見とするが、あまり用いられず、江戸時代の後期に時々 変わった形式として採用される程度で、尼垂木様木鼻、 化精尾垂木、擬尼垂木、など様々にいわれて、この部材 に広く通用する名称がつけられていない。

本稿では、筆者が命名これまでの発表論文で使用して きた化粧尾垂木を仮に使用してよぶこととする。

この化籸尾垂木は、中国では晋而聖母殿下層軒組（表 2，図12）を初見とする。しかし、この形態は、第 4 節 でくわしく述べるように、水平肘木の組み上げ軒組（表 2 で華とあるもの）系統の时木鼻の変化したものと考え られ、尼垂木が次第に簡略化してゅき（表 2 ，図14・17・ 23）、営造法式の図（表 2，図24）に示されている形式 が成立・具体化された初見事例として善化寺大殿（表 2 ，図22）があげられる。

さらに、進んで1100年代末の臨汾大中楼では、完全な 形の化粧尾垂木(仮昂)がみられる。

元代に入ると陽和楼（表 2 ，図28）のように尾垂木之 化粧尾垂木を混合する軒組なども出現する。1300年代以 降は詰組では、(仮昂) と（昂）の軒組をもつ建築が中 心となって建設が行われてゆく。しかし、かつての遼・ 金など北部の地域では（仮昂）の使用例が非常に多いこ とは注目される。

そして、肘木重ねによる軒組は、化粧尾垂木付の軒組 に吸収されたと考えるのが妥当であろう。

これらをまとめると、

1. 疎組系の形式は、唐以降、大きな技術的進展は みられた跡がなく、住它系の遺構に多用されるこ とが確認できる。

2. 疎組系で華林寺大殿のように福建を中心とする 南部で血斗付斗、さし时木などの形式がみられる。

3. 詰組系では、3つのタイプの軒組があり、それ ぞれ異なった進展を遂げている。

尾垂木使用の軒組は、唐以前から清代に至るまで全地域 で多用される一方、1000年を過ぎて尾垂木の簡略化が始 まり、営造法式に化粮尾垂木の祖形がみられ、1100年末 には完全な化精尾垂木の形式が成立した。

化粧尾垂木による軒組は、前述したように、営造法式 に示されて以降、事例が次第に増加の傾向にあり、元代 以降多用される。

\section{3. 中国建築の高麗建築への影響}

表 1 に記載のように中・朝交流については杉山信三博 土の詳細な研究があり、この成果に目う所が多い。中 国の政変が一応のおさまりをみせると、再び、両国間に 交流が始まった。末の商人の往来と外交交流、さらには 禅宗の導入が、我国よりやや早く、12世紀前半から始ま っていた。（注11）残念ながら遺構が残されていないた め、当時どのような形式の建築があったのか知ることが できない。

元の建国は、南末の圧迫と高麗朝への圧力となり、高 麗政府は江華島へ移り（1232～70年）、南朱との交易を 通じて交流を続け、この間に大蔵経木版刻（現・海印寺 蔵）事業を行うなど、仏教への信頼は変わらず続いたよ うである。（注 2）

やがて江華島を出た政府は、新たに王位についた忠烈 王とその元朝一族の血を引く王妃によって元風の文化が 


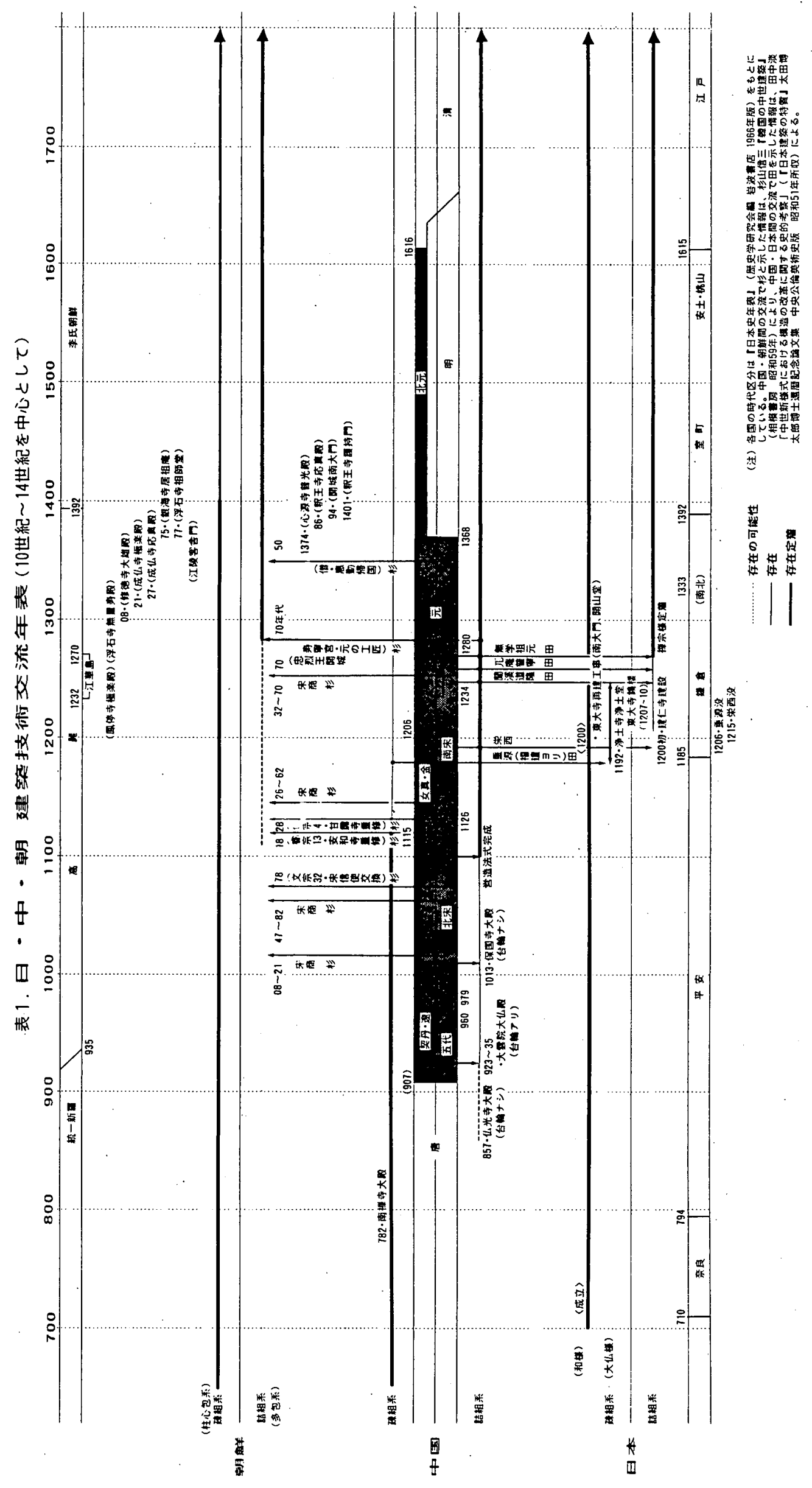




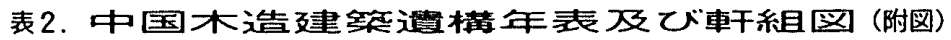

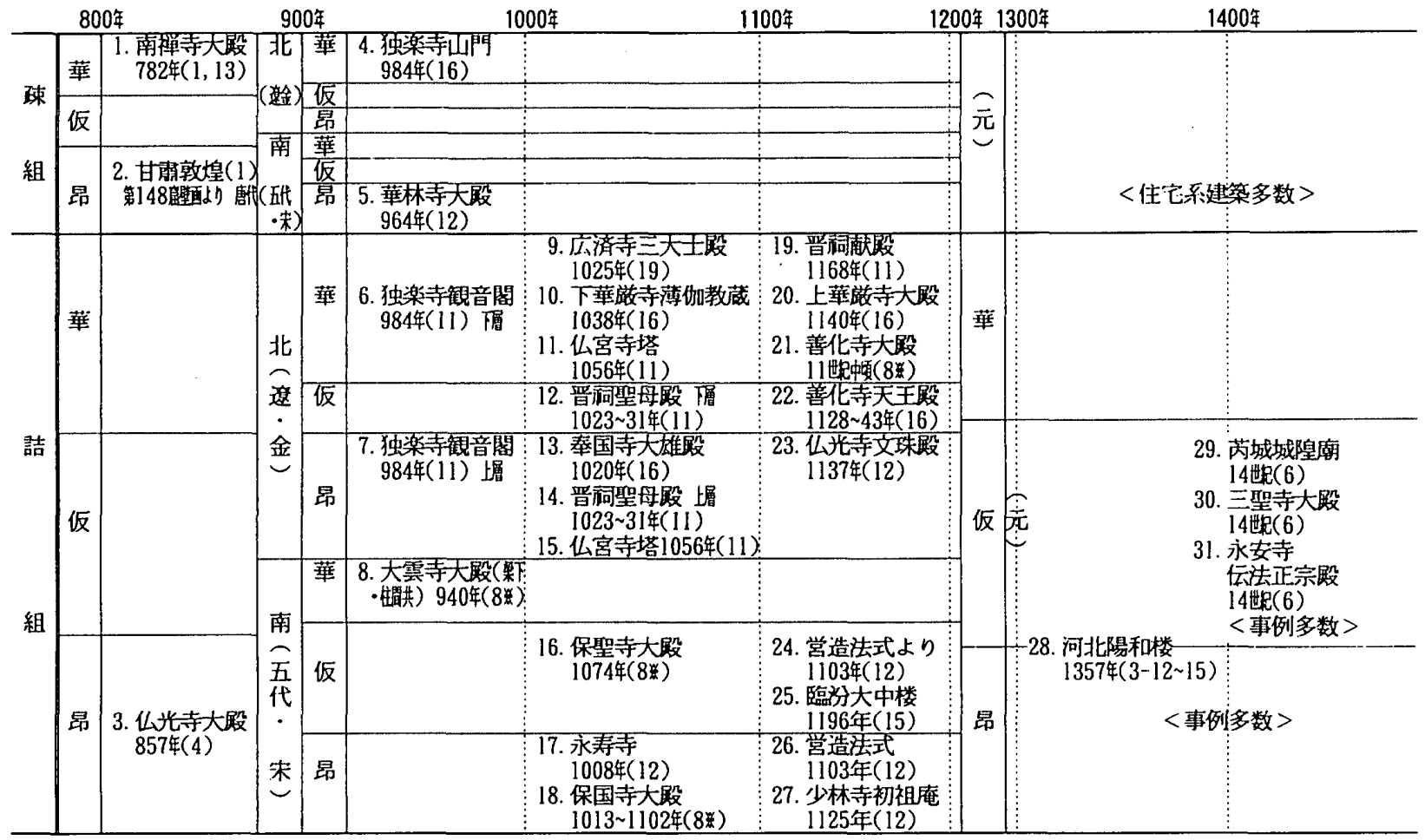

註）建築名の前の数字は付図の番号を、うしろは建筑年代を示す。 また、( )内の数字は参考文献中の中国関係の番号を、※付は 日本関係の番号を示守。

11、15、16は類似の形式のため省略

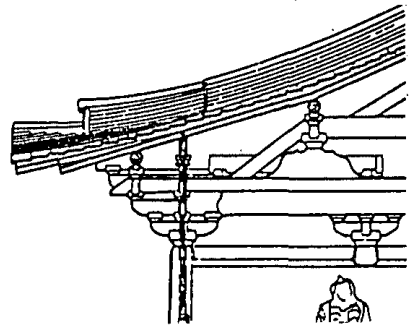

1. 南禅寺大殿

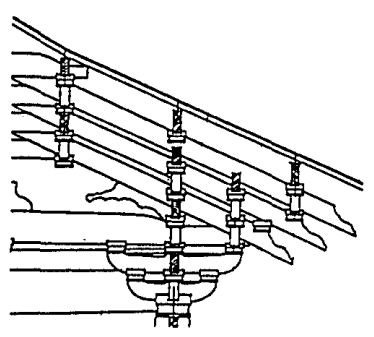

5. 華林寺大殿

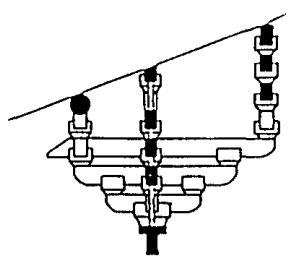

8. 大雲寺大殿

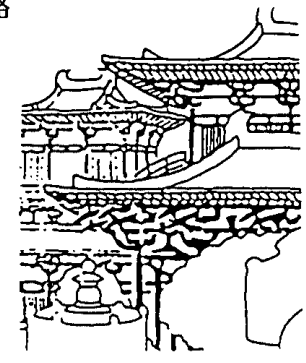

2. 甘更敦煌(1)

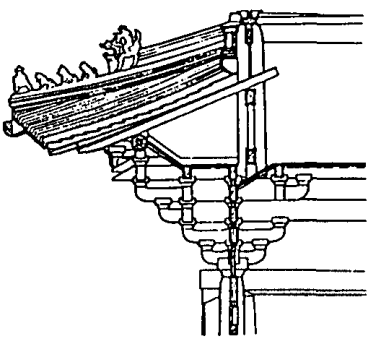

6. 独楽寺観音閣 下層

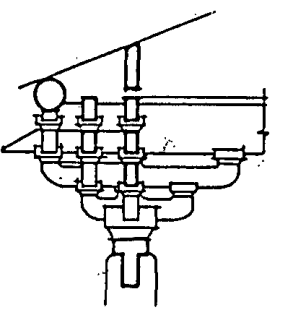

9. 広済寺三大士殿

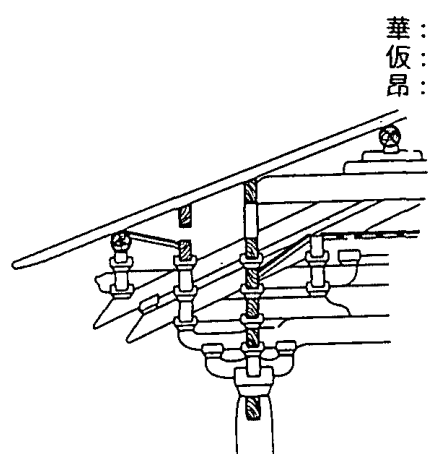

3. 仏光寺大殿

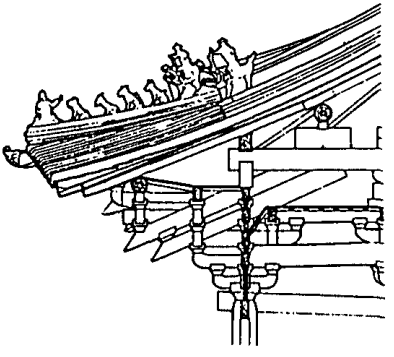

7. 独楽寺観音閣 上層

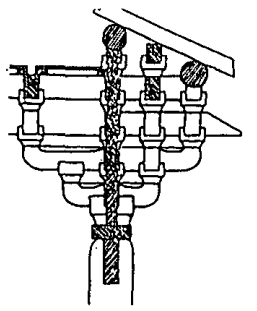

10. 下華撖寺薄伽教葴

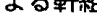

仮昂による軒組

: 昂による軒組

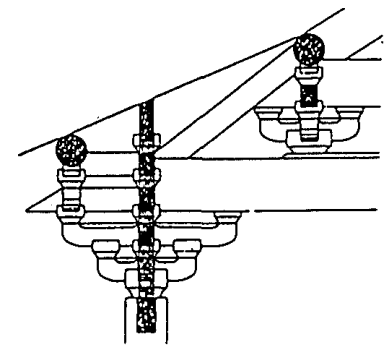

4. 独楽刲山門

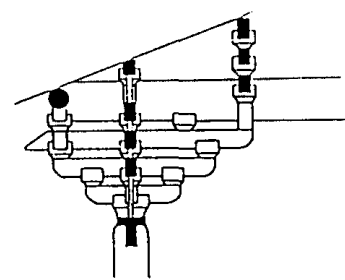

8. 大雲寺大殿

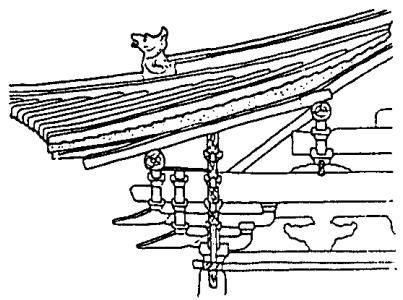

12. 晋柌聖母殿 


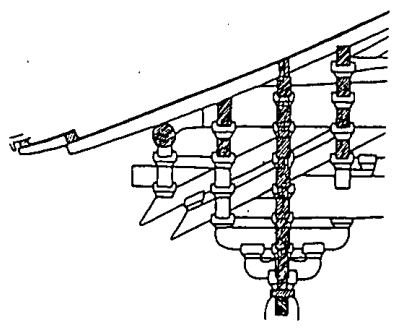

13. 奉国寺大雄殿

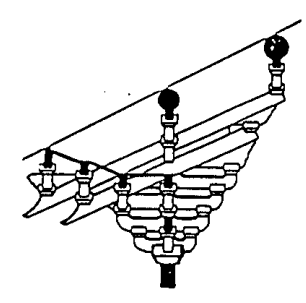

18. 保国寺大殿（柱間）

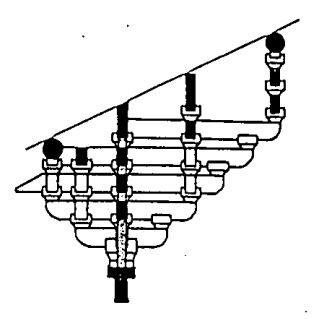

21. 善化寺大殿（柱間）

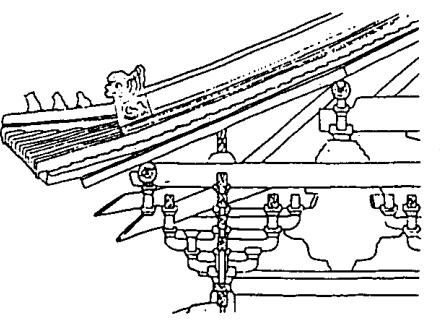

14. 晋蒚聖母殿

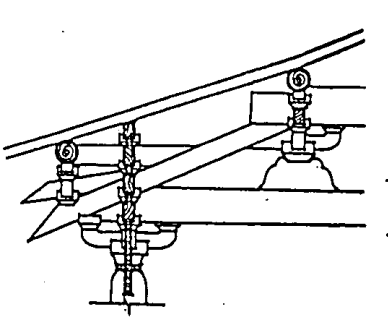

17. 永寿寺

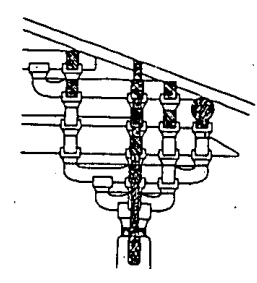

20. 上華嚴寺大殿

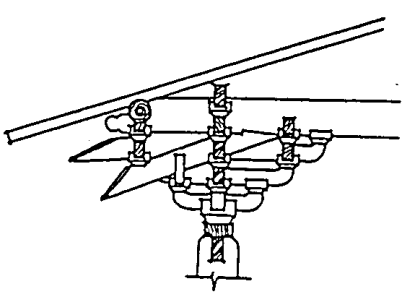

23. 仏光侍文珠殿

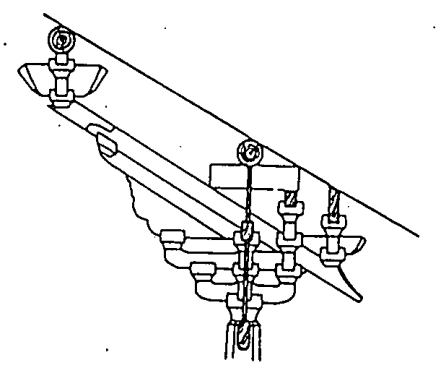

27. 少林寺初祖庵

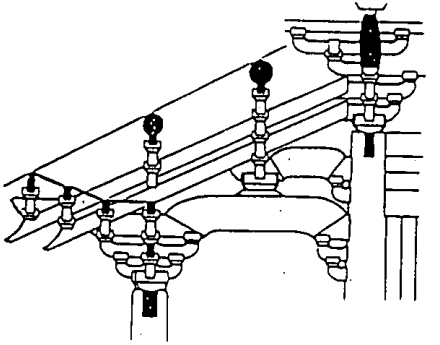

18. 保国寺大殿（柱上）

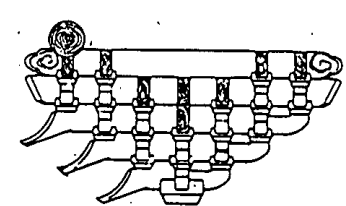

25. 臨多大中楼

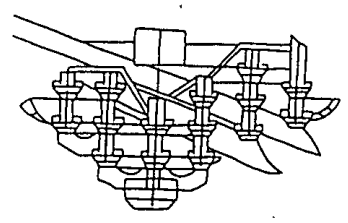

26. 営造法式

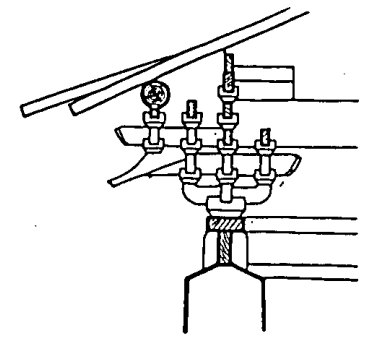

30. 三聖寺大殿

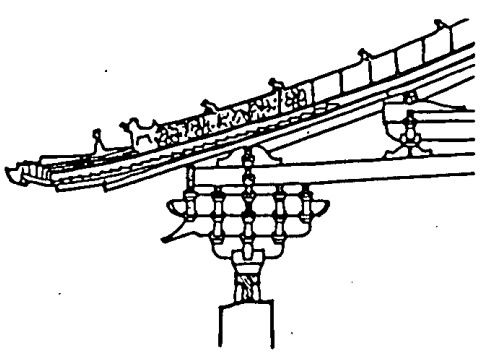

31. 永安寺

伝法正宗殿

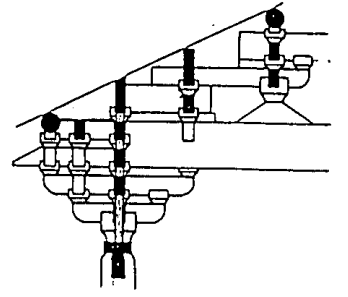

21. 善化寺大殿 (柱上)

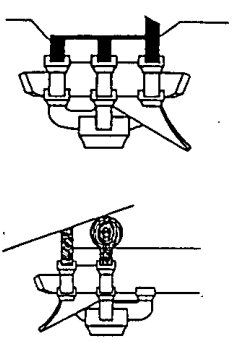

24. 営造法式より

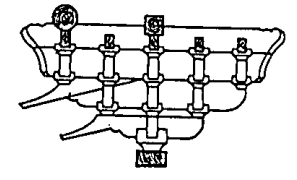

29. 芮城城隍廟 
表 3-1高殿時代ニ造遭模

(柱心包系)柾組

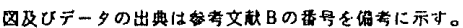

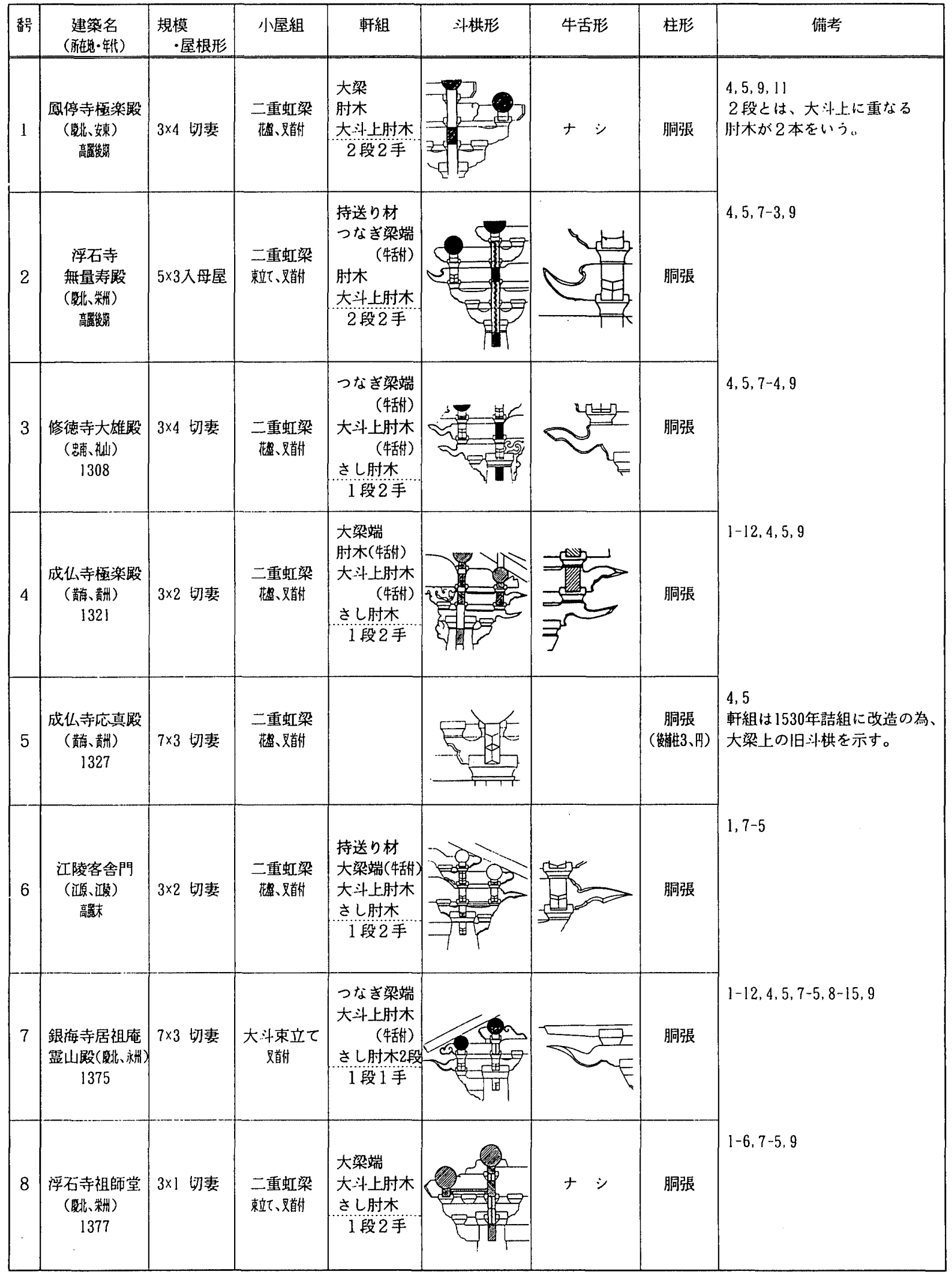


(多包系)詰組

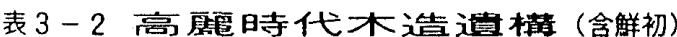

\begin{tabular}{|c|c|c|c|c|c|c|c|c|}
\hline 番号 & 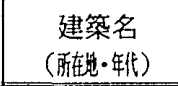 & $\begin{array}{l}\text { 規模 } \\
\text { ・屋根形 }\end{array}$ & 小屋組 & 軒組 & 斗栱形 & 牛舌形 & 柱形 & 備考 \\
\hline 1 & 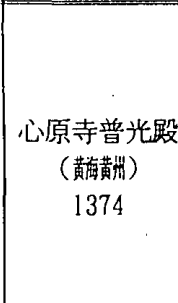 & $3 \times 3$ 入母屋 & $\begin{array}{l}\text { 二重虹梁 } \\
\text { 双首、束立て }\end{array}$ & 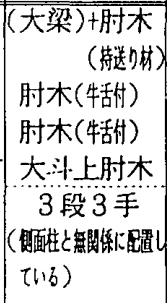 & & & 胴張 & $\begin{array}{c}\text { 1-12,4,5 軒組説明の中()は柱 } \\
\text { 上と柱間で異なる" }\end{array}$ \\
\hline 2 & $\begin{array}{c}\text { 粎王寺応真殿 } \\
\text { (葡、㚳) } \\
1386\end{array}$ & $5 \times 2$ 切妻 & & $\begin{array}{r}\text { (大梁) }+ \text { 胿木 } \\
\text { (特甜) } \\
\text { 大斗上肘木 } \\
2 \text { 段 } 2 \text { 手 }\end{array}$ & 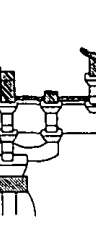 & & 円·粽付 & $\begin{array}{l}\text { 1-6(军真による) } \\
4 \\
\text {. }\end{array}$ \\
\hline 3 & $\begin{array}{c}\text { 開城南大門 } \\
\text { (京㘶、關) } \\
1394\end{array}$ & $3 \times 2$ 入母屋 & $\begin{array}{c}\text { 二重虹梁 } \\
\text { 束I工 }\end{array}$ & 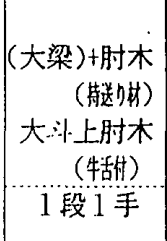 & & & 円·粽付 & $1-13$ \\
\hline 4 & 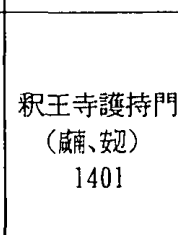 & $3 \times 2$ 切事 & $\begin{array}{l}\text { 二重虹梁 } \\
\text { 束立て }\end{array}$ & 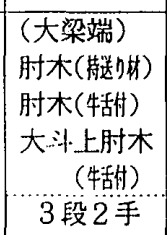 & & & 胴張 & $1-12,4,8-15$ \\
\hline
\end{tabular}

積極的に導入されることとなり、元より工匠を呼び、開 城に寿寧宮を建設した。ここでは、間違いなく元の技術 の導入があったといえよう。こうした背景の下に、表 1 に示すように1200年代からの踈組系の、次いで1300年代 後半に建設された詰組系の建築の遺構が残されている。 (表 $3-1,2$.)

疎組系 8 棟、詰組系 4 棟（釈王寺護持門は李朝時代に 入っているが、技術的には高麗時代の建築と考えて加え ている）についての建築年代については、杉山博士等先 学の研究と、韓国文化財研究所による調査報告、朝鲜民 主主義人民共和国朝鮮遗跡造物図鑑編集委員会の見解な どを参考に、表 3 のように决定した。

疎組系建築様式について

これについては、古くは関野 貞博士によって明治 36 年からの調査を踏まえて、疎組系の建築を日本の天竺様 に、詰組系の建築を唐様に対比して分類されたが、これ を更らに詳しく論考した藤島亥治郎博士の研究 (注12) があり、やはり大仏様と同様の様式の導入があり、形式 上の分化があり、さらに禅宗様の様式の導入による折事 化を行いつつ独自の変化をしたとする説を立てておら㧈 る。(注12)

その後、また、杉山信三博士が、疎組系が旧来の伝統 的な形式のもの（疎組第一形式）、南年の影篭による形 式のもの（疎組第二形式）、詰組系の元の様式の影響に よる形式のもの（疎組第三形式）のように形式分化した ものとする説を立てられた（注13）。こられの先学の研 究成果を視野に入れつつ、考察を進めたい。

まず、表 1 に示すとおり、残されている遺構の建築年 代をみる、疎組系が詰組系より約150～200年古くから
のものが残り、全体の数も多い。そして、年代を追って みると、疎組系では江華島政府以前の 1 棟、それ以後、 1300年初頭期のもの 4 棟、1300年末のもの 3 棟となって いる。詰組系ではすべて1300年末のものである。

これらの遺棈が現存したことは、様々な条件が重なっ たとはいえ極めて偶然性の高いものによることから、こ こから直ちに何かをいうことは危険ではあるが、時代背 景との関係でみるとなかなか意味の深いものがある。

江華島以前すなわち元の影響のなかった時代の高麗建 築唯一の遺構鳳停寺極楽殿は、11世紀、12世紀と中国南 北、特に末之の交流の中で、建築文化導入の可能性はあ るものの、中国ではまだ詰組系の技術様式が武行されつ つあった時代で、旧来からの疎組系の技術と様式が存在 していた時代でもあったことから、朝鮮古来の伝統を継 承した事例と見ることができる。すなわち、胴張り柱上 に曲面斗繰りの斗を置き、时木を重ね、その上に梁を固 く。小屋組は、二重虹梁を幕股（花盤）で受け、棟木は 、叉首受けとする唐代南禅寺大殿にも共通する形式の遗 櫣である。（注14）

次いで、表 3-1の 2〜5の事例であるが、梁及び时 木先に (牛呫) がつくこと、典斗がつくこと、さし时木 が用いられることが変化として表れる。

（柱心包系）の牛舌については、陉稿（注15）で検証 したように、中国における発展経過をみると、木鼻から つくり出されたものと、尼垂木を簡略化していって形式 化したものとがあり、（柱心包系）は、前述した中国と の交流関係と形態上、时木成内でつくり出さ扎ているこ とから、中国の影響を受けた前者に属するものと解され る。 
このような変化は、(柱心包系) 建築の形式がまだ主 流であったとき、刻々伝えられる中国建築の技術様式が (柱心包系) 建築で受け止められ、時代の中で変化して いた結果であり、日本のように新しい様式（大仙様）と して受け入れられなかったと解する。

1270年代の開城寿寧宮の建設以後、間違いなく元の工 匠を通じて、尾垂木をもたない肘木の重的合わせによる 軒組から成る元風の詰組（多包系）を普及させていった ものと解されるが（両国の交流関係の樑さからも）、そ れが (柱心包系) に影響して、変化したのが表 $3-1$ の $7 ， 8$ の遺構事例といえる。

斗尼が直線につくり出されるが、これは、元末の変化 と対応する変化であり、加工上からは細工が容易となる ことから、一種の簡略化と見ることが出来よう。

このように、（柱心包系）の建築は、伝統的な唐以前 にもつながる形式を継承してきたが、高麗時代の後期以 後、中国の建築の発展と、その技術様式の導入がはから れる中で、時々の形式を受け入れて変化を重ねていった。

従って、高麗時代の (柱心包系) 建築形式は、固定し た様式を確立したものではなく、羿化の過程にあると考 えたほうが妥当である。

朝鮮では、日本のように旧来からの形式「和様」が一 方で使われながら、平行して、桨化した形式「大仙様」 が使われるということがなかった。

従って、その変化は、形式の確立をいう程に明確な分

注 1 高麗史」(李朝5代文宗1451年 6代端宗1454年編集)

注 2 参考文献・朝鲜関係A -2

注 3 参考文献・朝鲜関係 $\mathrm{A}-1$

注 4 参考文献・中国関係にも重要遗構として研觉者に 㲅知されている遗構。

注 5 䫓貫材の断面が、柱筋上の析あるいは、通时木の 断面と比へて、南禅寺大殿では等しいか、仙光寺 大殿では偩の方が大きくなっており、棰造的な配 虏かなされた結果と考える。

注 6 参考文献・中国関係17
類を行い整理するよりも、ひとつの様式上の変化ととら えた方が朝鮮建築の木造技術の発展を理解する上で妥当 と考える。(柱心包系) の建築が様式としてのアイデン ティティであるかのように、胴張り柱に固執し、木鼻形 の (牛舌) を形状は様々にあるものを守り、さし时木を 用いることで (多包系) 建築との違いをもたせた。

また、肘木端部を斜めに切ることと（旧来の形式を残す 鳳停寺極楽殿を除いて）、下端に S 字形の繰り形をつけ ることは、中国にもみられない形式で注目されるが、こ れもこの系統の特幑之なっている。

詰組系 (多包系) 建築様式について

表 $3-2$ に示す 4 棟の遺構は、表 2 に示す元代の（仮 昂）付の系統に類するもので、前述の歴史的背景ともあ いまって元の (仮昂) 系の技術・様式を導入した結果と いえよう。その為、屁垂木の使用が全くみられず（李朝 時代1605年建築花敩寺極楽殿が現存する唯一の尾垂木使 用遗棈）、日本・中国と異なる朝鮮建築の構造上の特殊 性ともなった。

4. 結語

以上の考察から、次のことがまとめとしていえる。

1. (柱心包系)建築は、形式分類するほどに分化せず 系の中での変化の一部之見た方が妥当である。

2. (多包系)建築は、元の(仮昂)系の技術・様式を導 入発展した結果、尾垂木の使用がほとんどない。

注 7 参考文献・朝鲜関係 $\mathrm{B}-17$

注 8 参考文解・朝鲜関係B -6

注 9 参考文献・朝鲜関係B -17

注 10 参考文献・朝鲜関係 $\mathrm{B}-18$

注11 参考文献・朝鲜関係 $\mathrm{B}-19$

注 12 参考文献・朝鲜関係B -2

注13 参考文献・朝鲜関係B $\mathrm{B}-4$

注 14 参考文献・朝鲜関保 $B-17$

注15 参考文献・朝鮮関係B -16

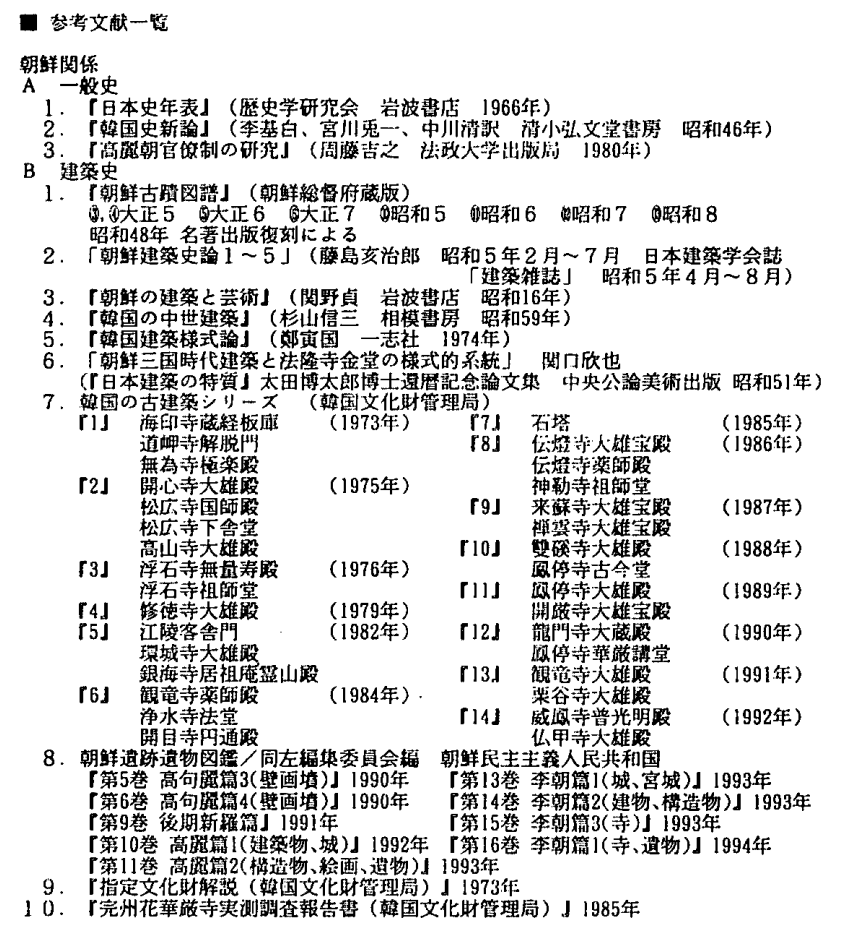

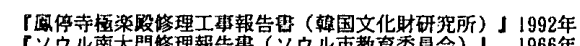
ソウル南大門修理報告書 (ソウル市教育委員会)」1966年

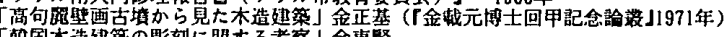

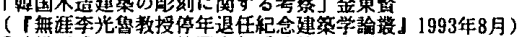

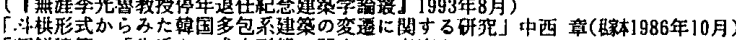

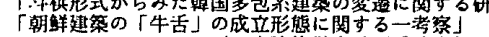

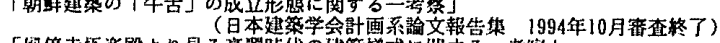

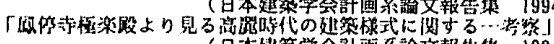

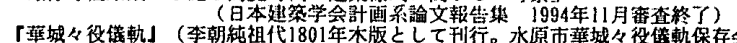

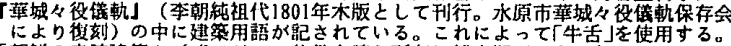
9.「朝鲜の寺院建築」(

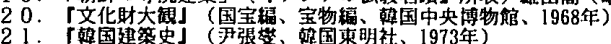
中医閏低

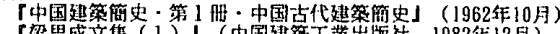

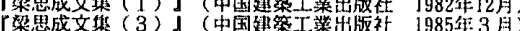

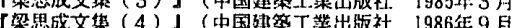

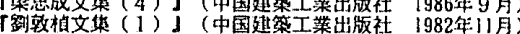
门科技史文策 第2 知了(上海出版社 1979年10月)

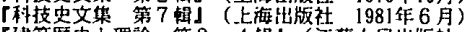

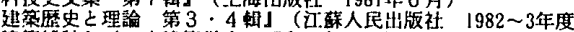
建勧雄誈了(日本建筑学全 昭和44年1月）

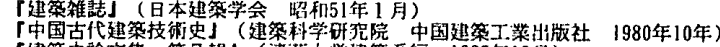

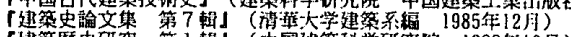

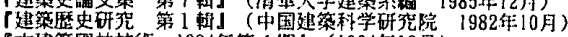
古建案国林技街1984年第4 4 期」(1984年12月)

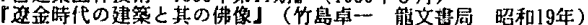

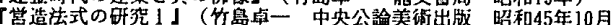
「中国壁画古境の建筑图と初唐建策の峨式について 田中㷋 ( 「東方学報」京都第 49 冊, 略和 52 年 2 月)

「消工部工程做法則例」架思成（中国営造学社刊，1934年）の中国建築工業出版社

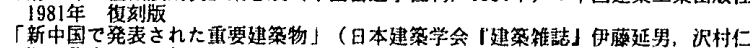

21. 阅口国の建筑」(969年1月)

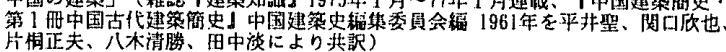

（1994年12月 1 日原稿受理，1995年 6 月22日採用決定） 